\title{
Penerapan Model Pembelajaran Predict-ObSerVE-EXPlain Berbasis KonteKstual UnTUK MeningKatKan AKTIVITAS dan PEMAHAMAN KONSEP SISWA SMP
}

\author{
Obimita Ika Permatasari $^{1}$, Putut Marwoto $^{2}$ \\ 1) SMK Walisongo Kaliori Rembang, Rembang, Indonesia \\ E-mail: obiem_mita@yahoo.com \\ 2) Pendidikan IPA S2 Universitas Negeri Semarang, Semarang, Indonesia \\ E-mail: pmarwoto@mail.unnes.ac.id
}

\begin{abstract}
Abstrak. Strategi Predict-Observe-Explain (POE) dikembangkan untuk mengetahui penguasaan siswa mengenai suatu konsep berbasis konstekstual. Tujuan dari penelitian ini adalah mendeskripsikan aktivitas dan penguasaan konsep tekanan serta menguji keefektifan penerapan model POE berbasis kontekstual dibanding dengan praktikum. Penelitian ini merupakan penelitian quasi eksperimen dengan desain control group pre-test post-test. Instrumen yang digunakan adalah lembar observasi untuk mengukur aktivitas siswa, tes untuk mengukur pemahaman konsep serta angket untuk mengetahui respons siswa terhadap model pembelajaran yang digunakan. Hasil analisis data diperoleh nilai aktivitas siswa sebesar 74,58 berada dalam kategori baik. Peningkatan pemahaman konsep menggunakan uji gain untuk kelas eksperimen dan kelas kontrol sebesar 0,53 dan 0,44. Selain itu, dari pengujian hipotesis menggunakan uji t satu pihak, diperoleh thitung $=4,15$ dan $t_{\text {tabel }}=1,67$ untuk pemahaman konsep. Keefektifan model pembelajaran yang digunakan adalah nilai post-test kelas eksperimen yang dibandingkan dengan KKM mata pelajaran IPA, diperoleh thitung $=6,84$, tabel $=$ 2,03 dan mendapat respons sebesar 86,65\%. Dari hasil penelitian tersebut, dapat disimpulkan bahwa penerapan model pembelajaran POE berbasis kontekstual dapat meningkatkan aktivitas dan pemahaman konsep siswa, serta efektif digunakan di dalam pembelajaran.
\end{abstract}

Kata Kunci: Aktivitas; Kontekstual; Pemahaman konsep; Predict-Observe-Explain

\section{Pendahuluan}

Perkembangan ilmu pengetahuan yang sangat cepat mengakibatkan pembelajaran Ilmu Pengetahuan Alam atau Sains tidak cukup jika hanya bertujuan membekali materi sebanyak-banyaknya terhadap siswa. Kemajuan ilmu pengetahuan dan kompleksnya tingkat berpikir siswa, menuntut guru atau pendidik untuk menciptakan pembelajaran yang inovatif.

Kegiatan belajar mengajar merupakan kegiatan inti dalam proses pendidikan. Belajar merupakan perubahan dalam perbuatan melalui aktivitas, praktek, dan pengalaman. Pembelajaran yang baik harus memberikan kesempatan luas kepada siswa untuk beraktivitas, baik hands-on activities maupun minds-on activities [1-2]. Pembelajaran seperti ini mengikuti prinsip pembelajaran konstruktivisme. Inti sari teori konstruktivisme adalah bahwa peserta didik harus menemukan dan mentransformasikan informasi kompleks ke dalam dirinya sendiri [3].

Kenyataannya pembelajaran yang terjadi saat ini di sekolah masih banyak berorientasi pada upaya menguji daya ingat siswa. Pembelajaran masih cenderung berbasis hafalan teori dan tidak didasarkan pada pengalaman siswa, sehingga kemampuan siswa sekedar dipahami sebagai kemampuan menghafal. Siswa kurang diberikan kesempatan untuk mengembangkan tanggung jawab, rasa ingin tahu, kejujuran, obyektif, kreativitas, toleransi, kecermatan bekerja, rasa percaya diri, mengenal hubungan antara masyarakat dan sains, dan menginterpretasikan gejala alam dari sudut prinsip-prinsip ilmiah.

Atas dasar inilah perlu diterapkan suatu model pembelajaran yang diharapkan mampu mengajak siswa untuk aktif di dalam proses pembelajaran. Guru dapat meningkatkan aktivitas siswa melalui pembelajaran yang berbasis laboratorium dan penyelidikan. Tujuan dari kerja praktek adalah untuk membantu siswa memperhatikan fenomena, untuk melihat secara rinci dari sebelumnya, dan untuk mengingat sesudahnya [4].

Model pembelajaran Predict-Observe-Explain (POE) merupakan strategi pembelajaran yang dikembangkan untuk mengetahui pemahaman siswa mengenai suatu konsep dengan pendekatan konstruktivis [5]. Strategi POE memberikan kesempatan bagi siswa untuk menghasilkan pengetahuan 
konseptual mereka sendiri melalui rekonsiliasi dan negosiasi antara pengetahuan awal dan pengetahuan baru [6-7]. Proses pembelajaran yang memenuhi model pembelajaran POE harus didukung dengan observasi oleh siswa secara langsung [8]. Dalam model pembelajaran POE ada tiga hal penting yang harus dilakukan oleh siswa pertama siswa terlebih dahulu melakukan prediksi jawaban terhadap pertanyaan yang diberikan, kemudian melakukan observasi untuk mengetahui kebenaran dari hasil prediksi atau untuk membangun pemahaman siswa agar materi yang dipelajari tidak bersifat abstrak, yang ketiga adalah tahap penjelasan, pada tahap ini siswa harus bisa menganalisis hasil prediksi dengan observasi jika jawaban mereka tidak sesuai dengan yang diobservasi maka siswa harus bisa memberikan penjelasannya secara logis sejalan dengan pembelajaran kontekstual. Pembelajaran dengan basis kontekstual dapat meningkatkan aktivitas dalam pelajaran dan menyambungkan konteks ke dunia nyata, integrasi konten sains dengan konten lainnya serta bidang keterampilan [9-10].

Berdasarkan uraian di atas, penelitian ini bertujuan untuk mengetahui diskripsi aktivitas dan pemahaman konsep siswa dengan menggunakan model pembelajaran POE berbasis kontekstual, serta mengetahui keefektifan model pembelajaran POE berbasis kontekstual dibandingkan model praktikum dalam meningkatan aktivitas dan pemahaman konsep tekanan SMP kelas VIII.

\section{METODE}

Penelitian ini merupakan penelitian quasi eksperimen yang menggunakan desain control group pre-test post-test dengan subjek siswa kelas VIII SMP Negeri 1 Rembang. Pengambilan sampel dalam penelitian menggunakan teknik purposif sampling untuk memperoleh kelas eksperimen dan kelas kontrol. Kelas eksperimen menggunakan model POE berbasis kontekstual, sedangkan kelas kontrol menggunakan model praktikum. Aktivitas siswa diukur dengan menggunakan lembar observasi, sedangkan pemahaman konsep menggunakan tes kemudian diuji dengan t-tes sampel berkorelasi. Keefektifan model pembelajaran POE berbasis kontekstual diuji dengan nilai post-test kelas eksperimen yang akan dibandingkan dengan KKM mata pelajaran IPA dan menggunakan angket respons untuk mengukur ketertarikan terhadap model pembelajaran.

\section{HASIL DAN PEMBAHASAN}

Pembelajaran dengan pendekatan konstektual POE untuk kelas eksperimen dan model praktikum untuk kelas kontrol. Diperoleh berbagai macam data antara lain data tentang aktivitas siswa, pemahaman konsep, dan keefektifan model pembelajaran. Aktivitas siswa diukur menggunakan lembar observasi, sedangkan pemahaman konsep dan keefektifan model pembelajaran diukur menggunakan istrumen tes.

Aspek keaktivan siswa yang diamati adalah: perhatian siswa terhadap penjelasan guru; kemampuan siswa mengkaitkan materi dengan kehidupan sehari-hari; menyiapkan alat dan bahan; kemampuan siswa merangkai alat; melaksanakan dan mencatat hasil praktikum; kemampuan siswa menganalisis dan menarik kesimpulan. Nilai aktivitas siswa dan pemahaman konsep seperti Tabel 1.

TABEL I

Nilai AKTIVITAS, PEMAHAMAN KONSEP Siswa Kelas EKSPERIMEN DAN KELAS KONTROL

\begin{tabular}{cccc}
\hline \multirow{2}{*}{ Kelompok } & $\begin{array}{c}\text { Aktivitas } \\
\text { Siswa }\end{array}$ & \multicolumn{2}{c}{ Pemahaman konsep } \\
\cline { 3 - 4 } & 74,58 & 44,57 & 73,94 \\
\hline $\begin{array}{c}\text { Kelas } \\
\text { Eksperimen } \\
\text { Kelas }\end{array}$ & Pretest & Post-test \\
Kontrol & 69,73 & 45,44 & 69,67 \\
\hline
\end{tabular}

Hasil analisis aktivitas siswa menggunakan uji $\mathrm{t}$ pihak kanan dengan taraf signifikan $5 \%$ didapat $t_{\text {hitung }}=2,82$ dan $\mathrm{t}_{\text {tabel }}=1,67$ sehingga disimpulkan bahwa aktivitas siswa kelas eksperimen lebih tinggi daripada aktivitas siswa kelas kontrol. Pencapaian nilai tiap aspek pada lembar observasi merata di masing-masing kelas yaitu $62,50 \%<\mathrm{N} \leq 81,25 \%$ dengan kriteria aktivitas baik. Keaktivan siswa dipengaruhi oleh berbagai faktor, diantaranya ketertarikan siswa terhadap proses pembelajaran, motivasi, dan rasa ingin tahu. Siswa mendapat dukungan tambahan untuk mengembangkan keterampilan yang terkait dengan keberhasilan untuk berpartisipasi dalam kelompok kecil [11]. Dalam hal ini yang dimaksud dukungan tambahan adalah pembelajaran berbasis laboratorium dengan model pembelajaran POE berbasis kontekstual. Kerja secara berkelompok dapat meningkatkan interaksi anggota, sehingga aktivitas meningkat.

Permasalahan muncul pada aspek kemampuan siswa menarik kesimpulan, baik kelas eksperimen dan kelas kontrol hanya mendapat skor 69,29\% dan 63,19\%. Kesulitan siswa untuk menganalisis dan menyimpulkan dari kegiatan yang telah dilakukan menyebabkan perolehan skor yang rendah.

Berdasarkan analisis data, rata-rata kemampuan pemahaman siswa mengalami peningkatan dari keadaan awal (pre-test) dan keadaan akhir (post-test) baik kelas eksperimen maupun kelas kontrol. Peningkatan pemahaman kelas eksperimen dapat dilihat dari rata-rata nilai pre-test dan posttest sebesar 44,57 dan 73,94 dengan gain 0,53 yang termasuk dalam kategori sedang, sedangkan peningkatan pemahaman pada kelas kontrol dapat dilihat dari rata-rata nilai pre-test dan post-test sebesar 45,44 dan 69,67 dengan gain 0,44 yang termasuk dalam kategori sedang. Hasil perhitungan menggunakan uji t pihak kanan dengan taraf signifikan $5 \%$ didapat $\mathrm{t}_{\text {hitung }}=4,15$ dan $\mathrm{t}_{\text {tabel }}=1,67$ menunjukkan bahwa peningkatan pemahaman konsep kelas eksperimen menggunakan model pembelajaran POE berbasis kontekstual lebih baik daripada kelas kontrol yang menggunakan model praktikum. Pembelajaran menggunakan model POE membuat siswa merasa lebih tertarik dan termotivasi dalam belajar. Strategi POE dikembangkan untuk menemukan kemampuan memprediksi, dan alasan dalam membuat prediksi tersebut mengenai gejala sesuatu [12]. Pembelajaran POE berawal dari sudut pandang siswa dalam memprediksi suatu persoalan.

Model POE berbasis konstektual dalam pembelajaran IPA bab tekanan memberikan efek positif terhadap aktivitas dan pemahaman konsep siswa. Karena di dalam proses 


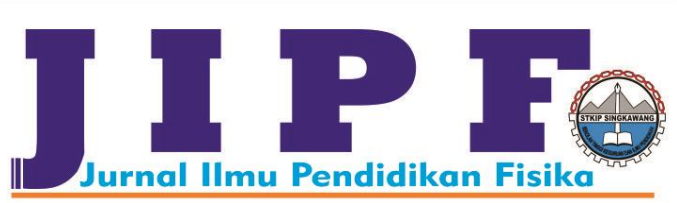

pembelajarannya berawal dari sudut pandang siswa sebagai pengetahuan awal bagi siswa dan di dukung dengan melakukan percobaan sehingga siswa akan menemukan konsep sendiri. Pengetahuan itu dibentuk kita sendiri yang sesuai dengan filsafat konstruktifisme.

Keefektifitasan model pembelajaran POE berbasisa kontekstual diuji menggunakan nilai post-test kelas eksperimen yang akan dibandingkan dengan KKM mata pelajaran IPA dan respon siswa. Hasil angket respons $86,65 \%$ siswa merespons baik, berarti target $80 \%$ dapat terpenuhi. Hasil analisis keefektifan model pembelajaran dapat dilihat pada Tabel 2 dan Gambar 1.

TABEL III

Hasil ANALISIS KeEFEKTIFAN MODEL PEMBELAJARAN

\begin{tabular}{|c|c|c|c|c|c|}
\hline Model Pembelajaran & Nilai Post-test & Dk & thitung $_{\text {his }}$ & $\mathbf{t}_{\text {tabel }}$ & Kriteria \\
\hline POE & 73,94 & 34 & 6,84 & 2,03 & Ho diterima jika $t_{\text {hitung }}<\mathrm{t}_{\text {tabel }}$ \\
\hline
\end{tabular}

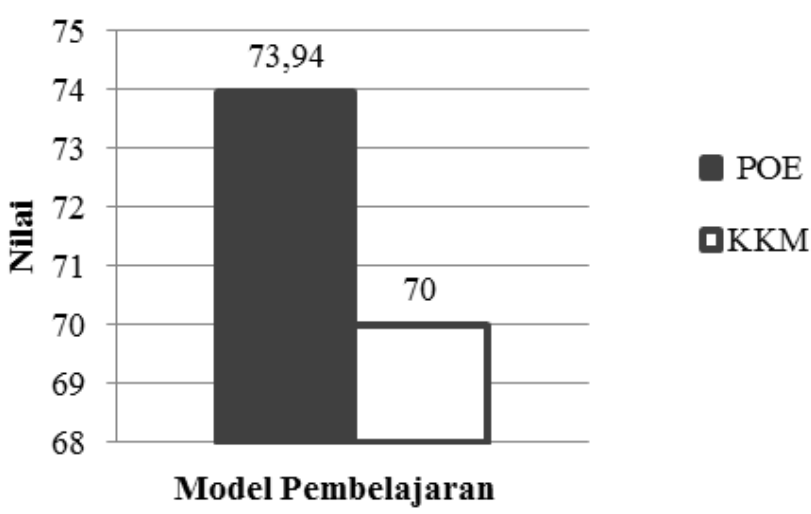

Gambar 1. Perbandingan Nilai Pembelajaran Model POE dengan KKM

Aktivitas siswa berpengaruh terhadap proses belajar, proses belajar sangat berpengaruh pada pemahaman konsep seorang siswa dan keefektifan model pembelajaran sangat dipengaruhi oleh pemahaman konsep. Sehingga dapat diambil kesimpulan bahwa aktivitas siswa dan pemahaman konsep akan mempengaruhi keefektifan suatu model pembelajaran.

Keefektifan model pembelajaran POE berbasis kontekstual efektif meningkatkan pemahaman siswa disebabkan karena model pembelajaran dapat meningkatkan motivasi terhadap materi yang diajarkan, sehingga berakibat pemahaman konsep juga meningkat. Karakteristik pertama dalam pembelajaran efektif adalah memudahkan siswa belajar sesuatu yang bermanfaat, seperti fakta, keterampilan, nilai konsep dan bagaimana hidup serasi dengan sesama, atau sesuatu pemahaman konsep yang diinginkan [13]. Kontekstual sangat erat hubungannya dengan lingkungan dan lingkungan sekitar sangat berpengaruh terhadap pendidikan. Belajar efektif itu dimulai dari lingkungan belajar yang berpusat pada siswa.

\section{KESIMPULAN}

Hasil penelitian, pengujian hipotesis, dan pembahasan hasil analisis data yang telah dilakukan dapat ditarik kesimpulan bahwa aktivitas dan pemahaman konsep siswa dengan menggunakan model pembelajaran POE berbasis kontekstual lebih baik dari model praktikum. Penerapan model pembelajaran POE berbasis kontekstual dapat meningkatkan rasa ketertarikan siswa, motivasi dan rasa ingin tahu siswa.
Proses pembelajaran dimulai dari sudut pandang siswa bukan guru atau ilmuan, sehingga dapat meningkatkan penguasaan konsep dan efektif digunakan dalam pembelajaran IPA bab tekanan dengan $86,65 \%$ siswa merespons baik.

\section{UCAPAN TERIMAKASIH}

Penulis ucapkan terima kasih kepada Kepala SMP Negeri 1 Rembang yang telah memberikan tempat untuk melakukan penelitian ini.

\section{DAFTAR PUSTAKA}

[1] Wasis. 2006. "Contextual Teaching and Learning (CTL) dalam Pembelajaran Sains Fisika SMP". Cakrawala Pendidikan, 25(1): 1-16.

[2] Hamalik, O. 2009. Psikologi Belajar \& Mengajar (6th ed). Bandung: PT Grasindo.

[3] Rifa'i, A dan Catharina, T. A. 2011. Psikologi Pendidikan. Pusat Pengembangan MKU/MKDK-LP3: UNNES.

[4] Millar, R. 2001. Teaching and Learning Science Through Practical Work. Prosiding Outline of talk given at Nordlab-DK Seminar. Copenhagen.

[5] Rosdianto, H., Murdani, E., dan Hendra. 2017. The Implementation of POE (Predict Observe Explain) Model to Improve Student's Concept Understanding on Newton's Law. Jurnal Pendidikan Fisika Unimed, 6(1): 55-57. 
[6] Saowapak, T., Wanrawee, C., Pintip, R., dan Duangjai, N. 2007. "Development of a Predict-Observe-Explain Strategi for Teaching Flow Injektion an Undegraduate Chemistry". The Internasioal Journal of Learning, 17(3): 137-150.

[7] Liang, J. C. 2011. "Using POE to Promote Young Children's Understanding of the Properties of Air". Asia-Pasifik Journal of Rereach in Early Childhood Education, 5(1): 45-68.

[8] Kearney, M., Treagust, D. F., Yeo, S., dan Zadnik, M G. 2001. "Student and Teacher Perceptions of the Use of Multimedia Supported Predict-Observe-Explain Tasks to Probe Understanding". Jurnal Researh In Science Education. 31: 589-615.

[9] Glynn, S. M., dan Winter, L. K. 2004. "Contextual Teaching and Learning of Science in Elementary Schools". Journal of Elementary Science Education. 16(2): 51-63.

[10] Shamsid, I., dan Smith, B. P. 2006. "Contextual Teaching and Learning Practices in The Family and Consumer Sciences Curriculum”. Journal of Family and Consumer Sciences Education. 24(1): 14-27.

[11] Linda, W., dan Greg A. B. 2008. "Student Success Skills: A Structured Group Intervention For School Counselors". The Journal for Specialists in Group Work, 32(2): 190201.

[12] Wu, Y.T., dan Tsai, C.C. 2005. "Effects Of Constructivistoriented Instruction On Elementary School Students' Cognitive Structures". Jornal of Biological Education, 39(3): 113-119.

[13] Dunne, R. dan Wragg, T. Pembelajaran Efektif. Terjemahan Jasin, A. 1996. Jakarta: PT Gramedia. 